\title{
SS18 wt Allele
}

National Cancer Institute

\section{Source}

National Cancer Institute. SS18 wt Allele. NCI Thesaurus. Code C97801.

Human SS18 wild-type allele is located in the vicinity of $18 q 11.2$ and is approximately 74

$\mathrm{kb}$ in length. This allele, which encodes protein SSXT, plays a role in the positive regulation

of transcription. A chromosomal translocation $\mathrm{t}(\mathrm{X} ; 18)(\mathrm{p} 11.2 ; \mathrm{q} 11.2)$ of this gene and

either the SSX1, SSX2 or SSX4 gene is associated with synovial sarcoma. 